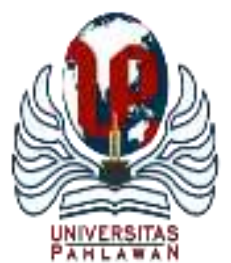

Edukatif : Jurnal Ilmu Pendidikan Volume 3 Nomor 6 Tahun 2021 Halm 4172 - 4185

EDUKATIF: JURNAL ILMU PENDIDIKAN

Research \& Learning in Education

https://edukatif.org/index.php/edukatif/index

\title{
Urgensi Menumbuhkan Motivasi Pelayanan Publik Pegawai Puskesmas: Analisis Servant Leadershipdan Mediasi Basic Need Satisfaction
}

\author{
Muhamad Agung Ali Fikri' ${ }^{\boxplus}$, Lala Hucadinota Ainul Amri², Multi Nadeak ${ }^{3}$, Dewiana \\ Novitasari $^{4}$, Masduki Asbari ${ }^{5}$ \\ Sekolah Tinggi Ilmu Ekonomi Insan Pembangunan ${ }^{1,4}$, Politeknik Negeri Media Kreatif ${ }^{2}$, Sekolah Tinggi \\ Teknologi Bandung ${ }^{3}$, STMIK Insan Pembangunan ${ }^{5}$ \\ E-mail : agungkuw@gmail.com ${ }^{1}$, lalahuca@polimedia.ac.id $^{2}, \underline{\text { multnadeaak@gmail.com }}^{3}$, \\ dhewiediosa@yahoo.co.id ${ }^{4}$, kangmasduki.ssi@gmail.com ${ }^{5}$
}

\begin{abstract}
Abstrak
Memotivasi pegawai layanan publik seperti para pegawai Puskesmas, lebih-lebih pada era pandemik ini, menjadi hal yang sangat krusial bagi setiap unit Puskesmas. Oleh karena itu, penelitian ini bertujuan mengukur korelasi pengaruh servant leadership terhadap motivasi pelayanan publik, baik secara langsung maupun tidak langsung melalui mediasi basic need satisfaction. Data dikumpulkan dari 73 pegawai Puskesmas, termasuk para dokter di dalamnya, yang bekerja pada Puskesmas di Kabupaten Tangerang. Metode penelitian yang digunakan adalah metode kuantitatif dan survei konfirmasi dengan bantuan software SmartPLS 3.0. Studi ini menunjukkan bahwa praktik servant leadership memberikan pengaruh positif dan signifikan terhadap motivasi pelayanan publik pegawai Puskesmas, baik secara langsung maupun tidak langsung melalui mediasi basic need satisfaction.
\end{abstract}

Kata kunci:Basic need satisfaction, motivasi pelayanan publik, servant leadership.

Abstract

Motivating publik service employees such as Puskesmas employees, especially in this pandemic era, is very crucial for every Puskesmas unit. Therefore, this study aims to measure the correlation of the influence of servant leadership on the publik servicesmotivation, either directly or indirectly through the mediation of basic need satisfaction. Data were collected from 73 Puskesmas employees, including the doctors in them, who work at the Puskesmas in Tangerang Regency. The research method used is a quantitative method and a confirmation survey with the help of SmartPLS 3.0 software. This study shows that the practice of servant leadership has a positive and significant impact on the publik servicesmotivation of employees at the Puskesmas, either directly or indirectly through the mediation of basic need satisfaction.

Keywords:Basic need satisfaction, publik service motivation, servant leadership.

Copyright (c) 2021 Muhamad Agung Ali Fikri, Lala Hucadinota Ainul Amri, Multi Nadeak, Dewiana Novitasari, Masduki Asbari

$\triangle$ Corresponding author

Email : agungkuw@gmail.com

DOI : https://doi.org/10.31004/edukatif.v3i6.1421

ISSN 2656-8063 (Media Cetak)

ISSN 2656-8071 (Media Online) 
4173 Urgensi Menumbuhkan Motivasi Pelayanan Publik Pegawai Puskesmas: Analisis Servant Leadershipdan Mediasi Basic Need Satisfaction - Muhamad Agung Ali Fikri, Lala Hucadinota Ainul Amri, Multi Nadeak, Dewiana Novitasari, Masduki Asbari

DOI: https://doi.org/10.31004/edukatif.v3i6.1421

\section{PENDAHULUAN}

Menumbuhkan motivasi kerja itu penting, karena motivasi kerja telah dikaitkan dengan kepuasan kerja(Novitasari, Asbari, \& Sasono, 2021a; Nugroho et al., 2021), inovasi (Asbari et al., 2020; Novitasari, Hutagalung, et al., 2021; Suroso et al., 2021a)dan kinerja(Asbari, Purwanto, et al., 2021; Asbari \& Novitasari, 2021; Johan et al., 2021a; Novitasari, Asbari, \& Purwanto, 2020; Novitasari \& Asbari, 2021a; Putra et al., 2021; Sudiyono et al., 2020). Di saat terjadi kelangkaan sumber daya manusia unggul, sementara tuntutan publik untuk terus menerus meningkatkan kinerja pelayanan Puskesmas, maka kemampuan pemimpin dan organisasi untuk meningkatkan motivasi kerja makin penting dan genting.

Dalam literatur administrasi publik, fokus telah dipusatkan pada konsep motivasi pelayanan publik (MPP). Didefinisikan sebagai "orientasi individu untuk memberikan layanan" kepada orangorang dengan tujuan berbuat baik bagi orang lain dan masyarakat" (Im et al., 2016; Mahmood et al., 2020; Tangaraja et al., 2015), MPP dapat dilihat sebagai jenis motivasi prososial tertentu (Jensen \& Bro, 2018; Shim \& Faerman, 2017). Dengan demikian, MPP sering dikontraskan dengan jenis motivasi lain yang didasarkan pada kesenangan yang melekat pada suatu kegiatan (motivasi pelayanan publik) atau imbalan yang diharapkan/penghindaran sanksi (peraturan eksternal). Penting, MPP tidak hanya mendorong pegawai untuk melakukan upaya menuju tugas yang menarik dan menyenangkan dengan konsekuensi prososial, tetapi juga membantu menjelaskan mengapa pegawai melakukan upaya ekstra tugas-tugas yang secara inheren tidak menyenangkan atau tidak memberi insentif dengan imbalan uang (Houston, 2011), membuatnya penting bagi para pemimpin publik untuk mengetahui bagaimana merangsang tipe ini motivasi (Johan et al., 2021b; Jumiran et al., 2020; Novitasari, Asbari, Putra, et al., 2021; Novitasari \& Asbari, 2021b; Suroso et al., 2021b).

Servant leadership memerlukan perilaku yang bertujuan untuk mengarahkan dan mengilhami upaya untuk memenuhi organisasi tujuan dengan mengartikulasikan visi yang meningkatkan kesadaran pegawai pentingnya nilai-nilai organisasi, misi, dan hasil. Bertujuan untuk membuat pegawai melampaui milik mereka sendiri kepentingan pribadi demi organisasi (Jensen et al., 2016; Podsakoff, MacKenzie, \& Bommer, 1996; benar, Moynihan, \& Pandey, 2012), strategi kepemimpinan ini adalah semakin diakui dalam literatur administrasi publik sebagai anteseden penting dari MPP (misalnya, Wright et al., 2012). Sementara studi empiris baru-baru ini menunjukkan positif korelasi antara servant leadership dan MPP (Krogsgaard, Thomsen, \& Andersen, 2014; Park \& Rainey, 2008; Vandenabeele, 2014; Wright et al., 2012), tidak satu pun dari studi ini mengintegrasikan jenis motivasi atau eksplorasi lainnya mekanisme yang mendasari hubungan ini. Harapan inti dalam teori servant leadership adalah bahwa transformasional pemimpin "mengaktifkan kebutuhan tingkat tinggi dari pegawai" (Wright et al., 2012, hlm. 207), tetapi harapan ini hanya sedikit diuji (lihat Hetland, Hetland, Andreassen, Pallesen, \& Notelaers, 2011; Kovjanic, Schuh, \& Jonas, 2013; Kovjanic, Schuh, Jonas, Quaquebeke, \& Dick, 2012), dan belum diteliti dengan motivasi sebagai hasil akhir.

Dalam artikel ini, penulis membangun wawasan dari penentuan nasib sendiri teori (SDT), karena memperkenalkan pentingnya basic need satisfaction (untuk otonomi, kompetensi, dan keterkaitan) dan memperkenalkan pemenuhan kebutuhan dasar sebagai mekanisme mediasi antara servant leadership dan motivasi pelayanan publik. Hal ini berdasar beberapa alasan: Pertama, memahami mekanisme psikologis melalui kepemimpinan organisasi dapat meningkatkan atau menggagalkan motivasi kerja pegawai sangat penting bagi pemimpin. Idealnya, pemimpin dapat menggunakan informasi tersebut dalam keputusan tentang cara memotivasi pegawai untuk 
4174 Urgensi Menumbuhkan Motivasi Pelayanan Publik Pegawai Puskesmas: Analisis Servant Leadershipdan Mediasi Basic Need Satisfaction - Muhamad Agung Ali Fikri, Lala Hucadinota Ainul Amri, Multi Nadeak, Dewiana Novitasari, Masduki Asbari

DOI: https://doi.org/10.31004/edukatif.v3i6.1421

mencapai tujuan organisasi(Asbari, Purba, et al., 2021b, 2021a). Kedua, motivasi adalah konsep multifaset (Wise, 2004), dan fokus pada motivasi pelayanan publik untuk masa pandemik ini dinilai lebih bermanfaat. Ketiga dan terakhir, mengintegrasikan teori SDT, servant leadership, dan MPP memiliki potensi untuk menjelaskan cara-cara tipe kepemimpinan servant leadership dalam membentuk persepsi pegawai tentang motivasi pelayanan publik yang lebih baik.

Servant leadership merupakan pendekatan kepemimpinan yang menekankan pada moral perilaku para pemimpin. Pendekatan ini berbeda dengan teori lain tentang kepemimpinan, seperti: kepemimpinan karismatik dan transformasional (Bass, 1985). Secara khusus, menurut Aboramadan (2020) dan Latif (2021), pendekatan servant leadership berbeda dari gaya kepemimpinan popular dalam beberapa hal: a) pemimpin yang melayani bertindak demi kepentingan terbaik pengikut mereka dan secara unik peduli dengan keberhasilan semua pemangku kepentingan organisasi; b) kepemimpinan yang melayani mencakup komponen moral; dan c) pemimpin yang melayani melakukan refleksi diri untuk mengurangi keangkuhan pemimpin. Spears (2010) secara empiris menunjukkan bahwa servant leadership berbeda dari kepemimpinan lainnya gaya, seperti LMX dan servant leadership.

Mengenai pentingnya kepemimpinan yang melayani untuk organisasi, studi literatur yang dilakukan oleh Parris dan Peachey (2013) baru-baru ini mengungkapkan bahwa kepemimpinan yang melayani adalah layak dan berharga pada tingkat individu dan organisasi dan itu meningkatkan keseluruhan efektivitas individu dan tim. Ketika praktik kepemimpinan yang melayani diimplementasikan dalam sebuah perusahaan, kinerja meningkat sebesar 15\%-20\%, dan produktivitas kelompok meningkat sebesar 20\%-50\% (Romig, 2001). Meskipun kepemimpinan yang melayani secara luas dipraktikkan di ruang rapat dan organisasi, itu tetap dipelajari (Bass dan Bass, 2008). Faktanya, hanya sejumlah kecil penelitian yang secara empiris memeriksa konstruk ini (Parris dan Peachey, 2013), yang baru-baru ini diidentifikasi sebagai dasar etika dan kerangka kepemimpinan yang diperlukan untuk mengatasi tantangan abad kedua puluh satu (Parris dan Peachey, 2013).

Menurut SDT, orang tidak hanya berbeda dalam hal bagaimana motivasi yang mereka miliki untuk melakukan suatu kegiatan tetapi juga dalam hal jenis motivasi di balik tindakan (Deci et al., 2017). Perbedaan mendasar dalam teori antara motivasi otonom dan motivasi terkontrol, ditentukan oleh apakah motivasi itu melibatkan "rasa" kemauan dan memiliki pengalaman memilih" atau "perasaan" tekanan dan harus terlibat dalam tindakan" (Gagné \& Deci, 2005, hal. 334). Jenis-jenis motivasi dapat dilihat sebagai bagian dari kontinum motivasi, di mana motivasi pelayanan publik adalah prototipikal otonom (Gagné \& Deci, 2005). Merujuk apakah suatu kegiatan dipandang secara inheren menarik atau menyenangkan (Ryan \& Deci, 2000b), motivasi pelayanan publik dikontraskan dengan jenis motivasi ekstrinsik lainnya, yang membutuhkan semacam alat antara aktivitas dan yang dapat dipisahkan dari hasil (Gagné \& Deci, 2005).

Ketika kegiatan tersebut dilakukan karena konsekuensi eksternal (atau "seolah-olah" eksternal). (seperti persetujuan implisit, imbalan nyata, atau meningkatkan harga diri), motivasi dikatakan ekstrinsik mengendalikan. Namun, ketika regulasi perilaku, dan nilai yang terkait dengannya, telah diinternalisasi ke sejauh konsekuensi eksternal tidak lagi diperlukan, motivasi dikatakan otonom secara ekstrinsik (Gagné \& Des, 2005). Menurut SDT, kasus terakhir terjadi ketika orang mengidentifikasi dengan nilai aktivitas (tidak menyenangkan) untuk tujuan yang mereka pilih sendiri, atau bahkan melihat perilaku sebagai bagian integral dari siapa mereka (tujuan, nilai, dan peraturan) dari suatu perilaku yang koheren dengan aspek-aspek lain dari kehidupan seseorang; Gagne \& Deci, 2005). Didefinisikan sebagai "orientasi individu untuk memberikan 
4175 Urgensi Menumbuhkan Motivasi Pelayanan Publik Pegawai Puskesmas: Analisis Servant Leadershipdan Mediasi Basic Need Satisfaction - Muhamad Agung Ali Fikri, Lala Hucadinota Ainul Amri, Multi Nadeak, Dewiana Novitasari, Masduki Asbari

DOI: https://doi.org/10.31004/edukatif.v3i6.1421

layanan" kepada orang-orang dengan tujuan berbuat baik untuk orang lain dan masyarakat" (Hondeghem \& Perry, 2009), MPP memiliki karakteristik otonom dan ekstrinsik. Ketika kegiatan publik yang dimotivasi oleh layanan didasarkan pada apa yang diharapkan pihak eksternal dari kegiatan (untuk berbuat baik), mereka mungkin melibatkan upaya yang diarahkan pada tugas-tugas yang tidak dilihat secara inheren menarik. Namun, hasil yang diharapkan tidak diarahkan pada (dan karena itu tidak mengendalikan) orang tersebut melakukan aktivitas. Sebaliknya, tugas-tugas seperti itu kemungkinan besar dilakukan karena "aktivitas itu perlu untuk hasil akhir" pemberian layanan atau karena tidak melakukan tugas tidak akan terpikirkan oleh orang-orang seperti mereka" (Houston, 2011).

Kepuasan kebutuhan juga telah dianggap sebagai fitur inti teori servant leadership (Podsakoff et al., 1996). Seperti dicatat oleh Kovjanic dan rekan (2012), itu adalah dengan menghargai dan menangani kebutuhan yang transformasional pemimpin mengembangkan potensi pengikutnya dan membina komitmen dan usaha mereka untuk kolektif (Asbari, Novitasari, et al., 2021; Novitasari et al., 2021; Purwanto et al., 2021; Purwanto, Bernarto, et al., 2020; Silitonga et al., 2021). Oleh karena itu penulis berpendapat bahwa SDT dan gagasannya tentang basic need satisfaction adalah komponen yang diperlukan untuk memahami bagaimana servant leadership menumbuhkan motivasi pelayanan publik. Penulis mengidentifikasi servant leadership mampu meningkatkan kepuasan pegawai.

\section{METODE PENELITIAN}

Penelitian ini mengadopsi teknik survei dengan menggunakan analisis kuantitatif dan untuk mengumpulkan data tentang pengaruh servant leadership terhadap motivasi pelayanan publik pegawai, baik secara langsung maupun tidak langsung melalui mediasi basic need satisfaction. Survei memungkinkan para peneliti untuk mengumpulkan data dari pegawai yang berpartisipasi dalam sesi training kepemimpinan yang dilakukan oleh atasan mereka, dan membantu mereka dalam menilai motivasi pelayanan publik pegawai yang dirasakan. Teknik ini diadopsi karena kemampuannya untuk mengumpulkan data dengan cepat dibandingkan dengan alat lain, sementara memungkinkan pemilihan sampel secara acak, dan memungkinkan peneliti untuk mengukur dan mengontrol beberapa variabel. Setelah itu, untuk mengidentifikasi temuan atau pola dalam sampel terkait, data yang terkumpul kemudian dianalisis secara mendalam. Tujuan dari penelitian ini adalah untuk mengumpulkan pengetahuan yang berguna secara maksimal untuk membentuk hipotesis yang valid, yang meminimalisir subjektifitas. Dengan demikian, teori positivis diadopsi dalam penelitian ini karena mengidentifikasi kesamaan yang terlihat melalui observasi dan investigasi kerja. Oleh karena itu, pendekatan deduktif diikuti, berusaha untuk mengusulkan dan menguji hipotesis untuk menyesuaikan teori yang ada.

Untuk kepentingan penelitian ini, kuesioner dirancang dalam beberapa bagian: Bagian pertama mencakup pertanyaan demografis di mana pegawai secara anonim nyatakan jenis kelamin, usia, pendidikan, dan masa kerja perusahaan. Bagian kedua mencakup lima pertanyaan yang menangkap sejauh mana servant leadership dipraktikkan diperusahaan. Item pengukuran (SER1-SER5) ini diambil dari Bande et al. (2016). Instrumen yang digunakan untuk mengukur basic need satisfaction diadaptasi dari Law et al. (2004) dengan menggunakan 6 item (BNS1-BNS6). Sedangkan instrumen yang digunakan untuk mengukur motivasi pelayanan publik diadaptasi dari Mehta et al. (2009) dengan menggunakan 7 item (MPP1-MPP7). Kuesioner dirancang sedemikian rupa untuk menargetkan dokter dan pegawai Puskesmas di Kabupaten Tangerang. Untuk memastikan kecukupan alat penelitian 
4176 Urgensi Menumbuhkan Motivasi Pelayanan Publik Pegawai Puskesmas: Analisis Servant Leadershipdan Mediasi Basic Need Satisfaction - Muhamad Agung Ali Fikri, Lala Hucadinota Ainul Amri, Multi Nadeak, Dewiana Novitasari, Masduki Asbari

DOI: https://doi.org/10.31004/edukatif.v3i6.1421

sesuai konteks, peneliti meneruskan kuesioner kepada empat peneliti yang catatannya kemudian dimasukkan. Selanjutnya, kuesioner diuji cobakan pada 30 pegawai. Para peneliti mengumpulkan data secara anonim sesuai dengan standar etika penelitian dan dapat menerima tingkat tanggapan yang cukup besar melalui komunikasi online. Lebih detil tentang item kuesioner penelitian ini bisa dilihat pada tabel 1.

Tabel 1. Daftar Item Penelitian

\begin{tabular}{|c|c|c|}
\hline Notasi & Item & Referensi \\
\hline \multicolumn{2}{|r|}{ Servant Leadership (SER) } & $\begin{array}{l}\text { Bande et al. } \\
(2016)\end{array}$ \\
\hline KEP1 & $\begin{array}{l}\text { Atasan saya meluangkan waktu untuk membentuk hubungan yang } \\
\text { berkualitas dengan dokter dan pegawai di Puskesmas. }\end{array}$ & \\
\hline KEP2 & Atasan saya menciptakan rasa kebersamaan antar pegawai. & \\
\hline KEP3 & $\begin{array}{l}\begin{array}{l}\text { Atasan saya menjadikan pengembangan pribadi } \\
\text { sebagaiprioritas. }\end{array} \\
\end{array}$ & \\
\hline KEP4 & $\begin{array}{l}\text { Atasan saya menyeimbangkan kekhawatiran mengenai detail sehari- } \\
\text { hari dengan proyeksi masa depan. }\end{array}$ & \\
\hline KEP5 & $\begin{array}{l}\text { Atasan saya bekerja keras untuk mengidentifikasi cara membantu } \\
\text { pegawai bawahannya untuk memperoleh kinerja terbaik masing- } \\
\text { masing. }\end{array}$ & \\
\hline \multicolumn{2}{|r|}{ Basic Need Satisfaction (BNS) } & $\begin{array}{l}\text { Law et } \\
(2004)\end{array}$ \\
\hline BNS1 & $\begin{array}{l}\text { Saya merasa dapat membuat banyak masukan dalam memutuskan } \\
\text { bagaimana pekerjaan saya selesai }\end{array}$ & \\
\hline $\mathrm{BNS} 2$ & $\begin{array}{l}\text { Saya memiliki peluang bagus untuk memutuskan sendiri bagaimana } \\
\text { caranya tentang pekerjaan saya }\end{array}$ & \\
\hline BNS3 & Saya merasa sangat kompeten saat bekerja & \\
\hline BNS4 & Hampir setiap hari saya merasakan pencapaian dari bekerja & \\
\hline BNS5 & Saya sangat menyukai orang-orang yang bekerja dengan saya & \\
\hline BNS6 & Saya merasa terhubung dengan orang-orang yang bekerja dengan saya & \\
\hline \multicolumn{2}{|r|}{ Motivasi pelayanan publik (MOT) } & $\begin{array}{l}\text { Lin \& Peng } \\
(2010)\end{array}$ \\
\hline SER1 & $\begin{array}{l}\text { Sulit bagi saya untuk menahan perasaan saya ketika saya melihat } \\
\text { orang-orang di kesulitan }\end{array}$ & \\
\hline SER2 & $\begin{array}{l}\text { Pekerjaan Saya sering diingatkan oleh kejadian sehari-hari tentang } \\
\text { betapa bergantungnya kita pada satu sama lain }\end{array}$ & \\
\hline SER3 & Penting bagi saya untuk berkontribusi pada kebaikan bersama & \\
\hline SER4 & Pelayanan publik yang berarti sangat penting bagi saya & \\
\hline SER5 & Saya percaya dalam menempatkan tugas di atas diri sendiri & \\
\hline SER6 & Saya siap berkorban untuk kebaikan masyarakat & \\
\hline SER7 & $\begin{array}{l}\text { Saya biasanya mengasosiasikan situasi politik dengan sesuatu yang } \\
\text { positif }\end{array}$ & \\
\hline
\end{tabular}

Dalam kaca mata Sekaran \& Bougie (2016) kerangka teoritis adalah fondasi yang mendasari seluruh proyek penelitian. Dari kerangka teori tersebut dapat dirumuskan hipotesis yang dapat diuji untuk mengetahui valid tidaknya teori yang dirumuskan. Kemudian selanjutnya akan diukur dengan analisis statistik yang sesuai. Mengacu pada teori dan penelitian sebelumnya, maka penulis membangun model penelitian sebagai mana disebutkan pada Gambar 1. 


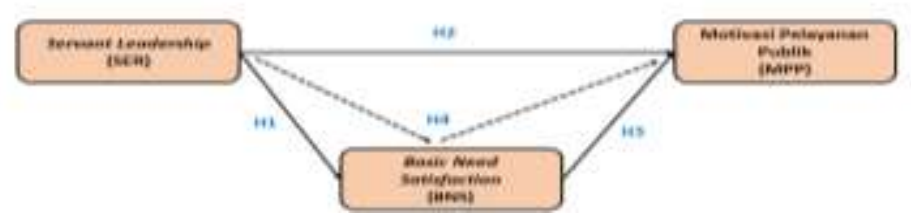

Gambar 1. Model Konseptual Penelitian

Berdasarkan penjelasan di atas, studi ini membangun hipotesis berikut ini:

Hipotesis 1 (H1): Servant leadership berpengaruh signifikan terhadap basic need satisfaction. Hipotesis 2 (H2): Servant leadership berpengaruh signifikan terhadap motivasi pelayanan publik. Hipotesis 3 (H3): Basic need satisfaction berpengaruh signifikan terhadap motivasi pelayanan publik.

Hipotesis 4 (H4): Basic need satisfaction memediasi hubungan antara servant leadership dan motivasi pelayanan publik.

\section{HASIL DAN PEMBAHASAN}

\section{Deskripsi Sampel}

Total ada 73 pegawai yang berpartisipasi. Responden memiliki kelompok umur yang berbeda-beda, berkisar antara di bawah usia 29 tahun (79.5\%), 30-49 tahun (13.7\%), dan lebih dari usia 50 tahun (6.8\%). Masa kerja mereka juga beragam, 54.8\% di antaranya di bawah 5 tahun, 27.4\% sudah bekerja antara 5-10 tahun, dan $17.8 \%$ sisanya telah bekerja lebih dari 10 tahun. Pendidikan tertinggi responden adalah mayoritas setingkat Diploma (75,3\%), kemudian Dokter (24.7\%).

\section{Hasil Uji Validitas dan Reliabilitas Indikator Penelitian}

Tahap pengujian model pengukuran meliputi pengujian validitas konvergen, validitas diskriminan. Sementara untuk menguji reliabilitas konstruk digunakan nilai cronbach's alpha dan composite reliability. Hasil analisis PLS dapat digunakan untuk menguji hipotesis penelitian jika seluruh indikator dalam model PLS telah memenuhi syarat validitas konvergen, validitas deskriminan dan uji reliabilitas (Purwanto et al., 2020; Purwanto, Asbari, \& Santoso, 2021b, 2021a; Purwanto, Asbari, Santoso, et al., 2019, 2021).

\section{Pengujian Validitas Konvergen}

Uji validitas konvergen dilakukan dengan melihat nilai loading factor masing-masing indikator terhadap konstruknya. Pada sebagian besar referensi, bobot faktor sebesar 0.7 atau lebih dianggap memiliki validasi yang cukup kuat untuk menjelaskan konstruk laten (Chin, 1998; Ghozali, 2014; Hair et al., 2010). Pada penelitian ini batas minimal besarnya loading factor yang diterima adalah 0.7, dan dengan syarat nilai AVE setiap konstruk > 0.5 (Ghozali, 2014). Setelah melalui pengolahan SmartPLS 3.0, hasil memperlihatkan bahwa seluruh indikator telah memiliki nilai loading factor di atas 0.7 dan nilai AVE di atas 0.5. Model fit atau valid dari penelitian ini dapat dilihat pada gambar 2. Jadi dengan demikian, validitas konvergen dari model penelitian ini sudah memenuhi syarat. Nilai loadings, cronbach's alpha, composite reliability dan AVE setiap konstruk selengkapnya dapat dilihat tabel 2.

\section{Pengujian Validitas Deskriminan}


4178 Urgensi Menumbuhkan Motivasi Pelayanan Publik Pegawai Puskesmas: Analisis Servant Leadershipdan Mediasi Basic Need Satisfaction - Muhamad Agung Ali Fikri, Lala Hucadinota Ainul Amri, Multi Nadeak, Dewiana Novitasari, Masduki Asbari

DOI: https://doi.org/10.31004/edukatif.v3i6.1421

Discriminant validity dilakukan untuk memastikan bahwa setiap konsep dari masing-masing variabel laten berbeda dengan variabel laten lainnya. Model mempunyai discriminant validity yang baik jika nilai kuadrat AVE masing-masing konstruk eksogen (nilai pada diagonal) melebihi korelasi antara konstruk tersebut dengan konstruk lainnya (nilai di bawah diagonal) (Ghozali, 2014). Hasil pengujian discriminant validity adalah dengan menggunakan nilai kuadrat AVE, yakni dengan melihat Fornell-Larcker Criterion Value diperoleh sebagaimana ditunjukkan pada tabel 3. Hasil uji validitas deskriminan pada tabel 3 di atas menunjukkan bahwa seluruh konstruk telah memiliki nilai akar kuadrat AVE di atas nilai korelasi dengan konstruk laten lainnya (melalui kriteria Fornell-Larcker), sehingga dapat disimpulkan bahwa model telah memenuhi validitas deskriminan (Fornell \& Larcker, 1981).

Selanjutnya dilakukan evaluasi collinearity untuk mengetahui ada tidaknya masalah collinearity pada model. Untuk menemukan collinearity tersebut, diperlukan statistik collinearity VIF dari setiap konstruk. Jika VIF lebih dari 5, maka model memiliki collinearity (Hair et al., 2014). Seperti yang ditunjukkan pada tabel 4, semua skor VIF kurang dari 5, yakni hasil dari model struktural collinearity mengungkapkan nilai VIF di bawah 2. Hal ini menunjukkan bahwa model penelitian ini tidak ada masalah multi kolinearitas.

\section{Pengujian Reliabilitas Konstruk}

Reliabilitas konstruk dapat dinilai dari nilai cronbach's alpha dan composite reliability dari masingmasing konstruk. Nilai composite reliability dan cronbach's alpha yang disarankan adalah lebih dari 0.7 (Ghozali, 2014). Hasil uji reliabilitas pada tabel 2 di atas menunjukkan bahwa seluruh konstruk telah memiliki nilai composite reliability dan cronbach's alpha lebih besar dari 0.7 (> 0.7). Kesimpulannya, seluruh konstruk telah memenuhi reliabilitas yang dipersyaratkan.

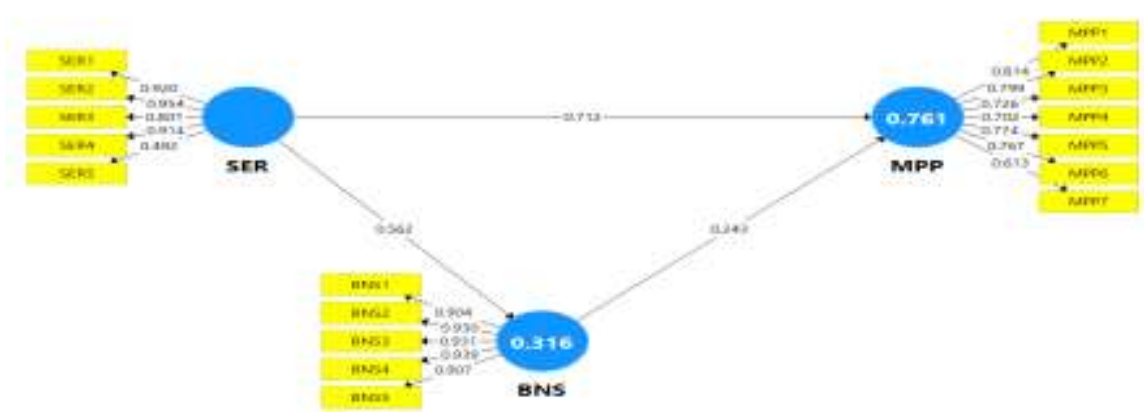

Gambar 2. Model Penelitian Valid

Sumber: Hasil Pengolahan SmartPLS 3.0 (2021)

Tabel 2. Items Loadings, Cronbach's Alpha, Composite Reliability, and Average Variance Extracted $(A V E)$

\begin{tabular}{lllllll}
\hline Variables & Items & $\begin{array}{l}\text { Loading } \\
\text { s }\end{array}$ & $\begin{array}{l}\text { Cronbach' } \\
\text { s Alpha }\end{array}$ & $\begin{array}{l}\text { Rho- } \\
\text { A }\end{array}$ & $\begin{array}{l}\text { Composite } \\
\text { Reliability }\end{array}$ & AVE \\
\hline Servant Leadership (SER) & SER1 & 0,920 & 0,880 & 0,924 & 0,916 & 0,695 \\
\hline & SER2 & 0,954 & & & & \\
\hline & SER3 & 0,801 & & & & \\
\hline & SER4 & 0,914 & & & & \\
\hline & SER5 & 0,492 & & & & \\
\hline Basic Need Satisfaction (BNS) & BNS1 & 0,904 & 0,956 & 0,958 & 0,966 & \\
\hline & BNS2 & 0,930 & & & & \\
\hline
\end{tabular}


4179 Urgensi Menumbuhkan Motivasi Pelayanan Publik Pegawai Puskesmas: Analisis Servant Leadershipdan Mediasi Basic Need Satisfaction - Muhamad Agung Ali Fikri, Lala Hucadinota Ainul Amri, Multi Nadeak, Dewiana Novitasari, Masduki Asbari

DOI: https://doi.org/10.31004/edukatif.v3i6.1421

\begin{tabular}{llllll}
\hline BNS4 & 0,939 & & \\
\hline & BNS5 & 0,907 & & \\
\hline Motivasi Pelayanan Publik (MPP) & MPP1 & 0,814 & 0,869 & 0,905 & 0,897 \\
\hline & MPP2 & 0,799 & & \\
\hline MPP3 & 0,726 & \\
\hline MPP4 & 0,702 & \\
\hline MPP5 & 0,774 & \\
\hline MPP6 & 0,767 & \\
\hline MPP7 & 0,613 & \\
\hline
\end{tabular}

Sumber: Hasil Pengolahan SmartPLS 3.0 (2021)

Tabel 3. Discriminant Validity

\begin{tabular}{lccc}
\hline Variables & BNS & MPP & SER \\
\hline & & & \\
\hline BNS & 0,922 & & \\
\hline MPP & 0,643 & 0,745 & \\
\hline SER & 0,562 & 0,849 & 0,834 \\
\hline
\end{tabular}

Sumber: Hasil Pengolahan SmartPLS 3.0 (2021)

Tabel 4. Collinearity (VIF)

\begin{tabular}{lccc}
\hline Variables & BNS & MPP & SER \\
\hline BNS & & & \\
\hline MPP & & & \\
\hline SER & 1,4600 & 1,461 & \\
Sumber: Hasil Pengolahan SmartPLS 3.0 (2021) & &
\end{tabular}

Tabel 5. Nilai $R$ Square

\begin{tabular}{|c|c|c|}
\hline \multirow{2}{*}{ Variables } & \multirow{2}{*}{ R Square } & R $\quad$ Square \\
\hline & & Adjusted \\
\hline BNS & 0,316 & 0,310 \\
\hline MPP & 0,761 & 0,757 \\
\hline
\end{tabular}

Tabel 6. Hypotheses Testing

\begin{tabular}{|c|c|c|c|c|c|c|c|}
\hline $\begin{array}{l}\text { Hypothese } \\
\text { s }\end{array}$ & Relationship & Beta & $\mathbf{M}$ & SE & $\begin{array}{l}\mathbf{T} \\
\text { Statistics }\end{array}$ & $\begin{array}{l}\text { P- } \\
\text { Values }\end{array}$ & Decision \\
\hline $\mathrm{H} 1$ & SER -> BNS & 0,562 & 0,568 & 0,045 & 12,382 & 0,000 & Didukung \\
\hline $\mathrm{H} 2$ & SER -> MPP & 0,712 & 0,716 & 0,037 & 19,044 & 0,000 & Didukung \\
\hline $\mathrm{H} 3$ & BNS -> MPP & 0,243 & 0,240 & 0,052 & 4,674 & 0,000 & Didukung \\
\hline $\mathrm{H} 4$ & SER -> BNS -> MPP & 0,137 & 0,136 & 0,031 & 4,415 & 0,000 & Didukung \\
\hline
\end{tabular}

Sumber: Hasil Pengolahan SmartPLS 3.0 (2021)

Pengujian Hipotesis

Edukatif : Jurnal Ilmu Pendidikan Vol 3 No 6 Tahun 2021 p-ISSN 2656-8063 e-ISSN 2656-8071 
4180 Urgensi Menumbuhkan Motivasi Pelayanan Publik Pegawai Puskesmas: Analisis Servant Leadershipdan Mediasi Basic Need Satisfaction - Muhamad Agung Ali Fikri, Lala Hucadinota Ainul Amri, Multi Nadeak, Dewiana Novitasari, Masduki Asbari

DOI: https://doi.org/10.31004/edukatif.v3i6.1421

Pengujian hipotesis dalam PLS disebut juga sebagai uji inner model. Uji ini meliputi uji signifikansi pengaruh langsung dan tidak langsung serta pengukuran besarnya pengaruh variabel eksogen terhadap variabel endogen. Untuk mengetahui pengaruh servant leadership terhadap motivasi pelayanan publik pegawai Puskessmas melalui basic need satisfaction sebagai variabel mediasi dibutuhkan uji pengaruh langsung dan tidak langsung. Uji pengaruh dilakukan dengan menggunakan uji t-statistik dalam model analisis partial least squared (PLS) dengan menggunakan bantuan software SmartPLS 3.0. Dengan teknik boothstrapping, diperoleh nilai $R$ Square dan nilai uji signifikansi sebagaimana tabel 5 dan tabel 6 .

Berdasarkan tabel 5 di atas, nilai $R$ Square basic need satisfaction (BNS) sebesar 0.316 yang berarti bahwa variabel basic need satisfaction (BNS) mampu dijelaskan oleh variabel servant leadership (SER) sebesar $31.6 \%$, sedangkan sisanya sebesar $68.4 \%$ dijelaskan oleh variabel lain yang tidak dibahas dalam penelitian ini. Sementara itu, nilai $R$ Square motivasi pelayanan publik (MPP) sebesar 0.761 yang berarti bahwa variabel motivasi pelayanan publik (MPP) mampu dijelaskan oleh variabel servant leadership (SER) dan variabel basic need satisfaction (BNS) sebesar 76.1\%, sedangkan sisanya sebesar 23,9\% dijelaskan oleh variabel lain yang tidak dibahas dalam penelitian ini. Artinya bahwa substansi pengaruh dalam model hubungan pada model penelitian ini adalah terbilang sangat kuat (Chin, 1998). Sedangkan tabel 6 menampilkan $t$-statistics dan p-values yang menunjukkan pengaruh antar variabel penelitian yang telah disebutkan

Peneliti menyajikan fakta korelasi pengaruh langsung dari servant leadership terhadap motivasi pelayanan publik (H2). Kedua, peneliti lanjutkan ke masing-masing syarat mediasi; yaitu, jalan dari servant leadership untuk basic need satisfaction $(\mathrm{H} 1)$ dan dari basic need satisfaction terhadap motivasi pelayanan publik (H3). Akhirnya, peneliti menguji signifikansi bersama dari hubungan tidak langsung tersebut (H4). Dari hasil pengujian yang dipaparkan pada tabel 6, ditemukan fakta bahwa seluruh hipotesis diterima (H1, H2, H3, H4 diterima/didukung). Peneliti mencatat bahwa data peneliti menemukan fakta dukungan parsial untuk jalur langsung dari servant leadership ke basic need satisfaction (H1) dan motivasi pelayanan publik (H3). Hal ini berarti persepsi pegawai/pegawai tentang perilaku pimpinan yang bersifat servant leadership sangat positif dan signifikan secara statistik terhadap basic need satisfaction dan motivasi pelayanan publik. Hasil ini menunjukkan bahwa pegawai/dokter mengekspresikan kesenangan dan kegembiraan yang lebih besar dalam pekerjaan ketika pimpinan mengandalkan servant leadership ke tingkat yang lebih besar. Untuk menilai hipotesis, peneliti menguji apakah servant leadership berhubungan langsung dengan motivasi pelayanan publik, dan secara tidak langsung melalui basic need satisfaction. Di sini, peneliti menemukan fakta hubungan pengaruh yang positif dan signifikan.

Hasil ini menguatkan gagasan tersebut dalam SDT bahwa kepuasan kerja sangat penting untuk meningkatkan motivasi pelayanan publik dalam setiap aktivitas pekerjaan (Fayzhall et al., 2020; Hutagalung et al., 2020; Jumiran et al., 2020; Novitasari, Asbari, Purwanto, et al., 2020; Novitasari, Asbari, \& Sasono, 2021b; Nuryanti et al., 2020; Sutardi et al., 2020; Yuwono, Novitasari, Asbari, et al., 2020; Yuwono, Novitasari, Hutagalung, et al., 2020), sedangkan kepuasan kerja sangat berkaitan dengan pengaruh positif dari servant leadership (Choi et al., 2016; Fayzhall et al., 2020; Weller et al., 2019). Hasil kerja penelitian ini didukung oleh para peneliti sebelumnya yang telah disebutkan di atas (Fikri et al., 2021). Jelasnya, peneliti mengientifikasi bahwa servant leadership mampu meningkatkan kepuasan kerja dan motivasi pelayanan publik.

Studi ini memiliki beberapa keterbatasan pada beberapa hal. Pertama, servant leadership, basic need satisfaction dan motivasi pelayanan publik semuanya diukur pada satu titik waktu, dan ini membuatnya sulit untuk ditentukan dengan jelas urutan temporal variabel secara empiris. Meskipun SDT secara eksplisit berpendapat sesuai dengan urutan kausal yang diusulkan dalam studi 
4181 Urgensi Menumbuhkan Motivasi Pelayanan Publik Pegawai Puskesmas: Analisis Servant Leadershipdan Mediasi Basic Need Satisfaction - Muhamad Agung Ali Fikri, Lala Hucadinota Ainul Amri, Multi Nadeak, Dewiana Novitasari, Masduki Asbari

DOI: https://doi.org/10.31004/edukatif.v3i6.1421

ini, yakni kepuasan dasar dalam bekerja yang meningkat akan meningkatkan motivasi pelayanan publik pegawai (Bidee et al., 2017; Goldman et al., 2017; Rezvani et al., 2017). Kedua, sampel hanya terdiri dari pegawai dan dokter Puskesmas di Kabupaten Tangerang, yang pemimpinnya (pimpinan) secara sukarela berpartisipasi dalam penelitian ini. Ini bisa menjadi masalah dalam hal generalisasi ke populasi pegawai/pegawai yang pemimpinnya tidak sukarela. Ketiga, populasi penelitian ini adalah pegawai Puskesmas, yang bisa jadi hasilnya berbeda jika penelitian ini dilakukan pada populasi industri lainnya, seperti ritel dan industri jasa yang sejenisnya.

\section{KESIMPULAN}

Studi ini berangkat untuk memeriksa apakah servant leadership berhubungan dengan motivasi pelayanan publik, baik secara langsung dan tidak langsung melalui basic need satisfaction di unit Fasilitas Kesehatan Puskesmas. Analisis empiris peneliti mengungkapkan beberapa hasil menarik: Pertama, servant leadership berpengaruh signifikan dan positif terhadap basic need satisfaction. Kedua, servant leadership berpengaruh signifikan dan positif terhadap motivasi pelayanan publik pegawai/dokter di Puslesmas. Ketiga, basic need satisfaction berpengaruh signifikan dan positif terhadap motivasi pelayanan publik pegawai/dokter. Keempat, basic need satisfaction memediasi pengaruh servant leadership terhadap motivasi pelayanan publik pegawai.

\section{DAFTAR PUSTAKA}

Aboramadan, M. (2020). Servant Leadership And Academics' Engagement In Higher Education: Mediation Analysis. Journal Of Higher Education Policy And Management, 42(6), 617-633. Https://Doi.Org/10.1080/1360080x.2020.1774036

Asbari, M., \& Novitasari, D. (2021). Pengaruh Authentic Leadership Terhadap Mentalitas Siap Berubah Dan Kinerja Pegawai Paruh Waktu. Business Management Journal, 17(1), 73-88. Https://Doi.Org/Http://Dx.Doi.Org/10.30813/Bmj

Asbari, M., Novitasari, D., \& Pebrina, E. T. (2021). Pengaruh Mediasi Mental Kesiapan Untuk Berubah Dan Work-Family Conflict Terhadap Kinerja Karyawan Di Masa Pandemi Covid-19. Mega Aktiva: Jurnal Ekonomi Dan Manajemen, $10(1), \quad$ 24-38. Https://Megaaktiva.Umkendari.Ac.Id/Index.Php/Jurnal/Article/View/123

Asbari, M., Purba, J. T., Hariandja, E. S., \& Sudibjo, N. (2021a). From Leadership To Innovation: Managing Employee Creativity. Jurnal Manajemen Strategi Dan Aplikasi Bisnis, 4(1), 143-154. Https://Doi.Org/Https://Doi.Org/10.36407/Jmsab.V4i1.287

Asbari, M., Purba, J. T., Hariandja, E. S., \& Sudibjo, N. (2021b). Membangun Kesiapan Berubah Dan Kinerja Karyawan: Kepemimpinan Transformasional Versus Transaksional. Jurnal Ilmiah Manajemen Dan Bisnis, 22(1), 54-71.

Asbari, M., Purwanto, A., Fayzhall, M., Goestjahjanti, F. S., Winanti, W., Yuwono, T., Hutagalung, D. D., Basuki, S., Maesaroh, S., \& Mustofa, M. (2020). Peran Kepemimpinan Transformasional Dan Organisasi Pembelajaran Terhadap Kapasitas Inovasi Sekolah. Edupsycouns: Journal Of Education, Psychology And Counseling, 2(1), 122-145.

Asbari, M., Purwanto, A., Sudargini, Y., \& Fahmi, K. (2021). The Effect Of Work-Family Conflict And Social Support On Job Satisfaction: A Case Study Of Female Employees In Indonesia. International Journal Of Social And Management Studies (Ijosmas), 1(01), 32-42.

Bande, B., Fernández-Ferrín, P., Varela-Neira, C., \& Otero-Neira, C. (2016). Exploring The Relationship 
4182 Urgensi Menumbuhkan Motivasi Pelayanan Publik Pegawai Puskesmas: Analisis Servant Leadershipdan Mediasi Basic Need Satisfaction - Muhamad Agung Ali Fikri, Lala Hucadinota Ainul Amri, Multi Nadeak, Dewiana Novitasari, Masduki Asbari DOI: https://doi.org/10.31004/edukatif.v3i6.1421

Among Servant Leadership, Intrinsic Motivation And Performance In An Industrial Sales Setting. Journal Of Business \& Industrial Marketing, $31(2), \quad 1-5$. Https://Doi.Org/Http://Dx.Doi.Org/10.1108/Jbim-03-2014-0046

Bidee, J., Vantilborgh, T., Pepermans, R., Willems, J., Jegers, M., \& Hofmans, J. (2017). Daily Motivation Of Volunteers In Healthcare Organizations: Relating Team Inclusion And Intrinsic Motivation Using SelfDetermination Theory. European Journal Of Work And Organizational Psychology, 26(3), 325-336. Https://Doi.Org/10.1080/1359432x.2016.1277206

Chin, W. (1998). The Partial Least Squares Approach To Structural Equation Modeling (E. Modern Methods For Business Research, In: G. A. Marcoulides (Ed.)). Lawrence Erlbaum Associates Publisher.

Choi, S. L., Goh, C. F., Adam, M. B. H., \& Tan, O. K. (2016). Transformational Leadership, Empowerment, And Job Satisfaction: The Mediating Role Of Employee Empowerment. Human Resources For Health, 14(1), 1-14. Https://Doi.Org/10.1186/S12960-016-0171-2

Deci, E. L., Olafsen, A. H., \& Ryan, R. M. (2017). Self-Determination Theory In Work Organizations: The State Of A Science. Annual Review Of Organizational Psychology And Organizational Behavior, 4(1), 19-43. Https://Doi.Org/10.1146/Annurev-Orgpsych-032516-113108

Fayzhall, M., Asbari, M., Purwanto, A., Goestjahjanti, F. S., Yuwono, T., Radita, F. R., Yulia, Y., Cahyono, Y., \& Suryani, P. (2020). Transformational Versus Transactional Leadership: Manakah Yang Mempengaruhi Kepuasan Kerja Guru? Edupsycouns: Journal Of Education, Psychology And Counseling, 2(1), 256-275. Https://Ummaspul.E-Journal.Id/Edupsycouns/Article/View/463

Fikri, M. A. A., Asbari, M., Hutagalung, D., Amri, L. H. A., \& Novitasari, D. (2021). Quo Vadis Motivasi Intrinsik Pegawai: Peran Strategis Kepemimpinan Transformasional Dan Kepuasan Kerja. Edukatif: $\begin{array}{llll}\text { Jurnal Ilmu } & \text { Pendidikan, }\end{array}$ Https://Edukatif.Org/Index.Php/Edukatif/Article/View/1397/Pdf

Fornell, C., \& Larcker, D. F. (1981). Evaluating Structural Equation Models With Unobservable Variables And Measurement Error. Journal Of Marketing Research, 18(1), 39. Https://Doi.Org/10.2307/3151312

Ghozali, I. (2014). Structural Equation Modeling, Metode Alternatif Dengan Partial Least Square (Pls) (4th Ed.). Badan Penerbit Universitas Diponegoro.

Goldman, Z. W., Goodboy, A. K., \& Weber, K. (2017). College Students' Psychological Needs And Intrinsic Motivation To Learn: An Examination Of Self-Determination Theory. Communication Quarterly, 65(2), 167-191. Https://Doi.Org/10.1080/01463373.2016.1215338

Hair, J. F., Black, W. C., Babin, B. J., \& Anderson, R. E. (2010). Multivariate Data Analysis (7th Ed.). Pearson Prentice Hall.

Hutagalung, D., Asbari, M., Fayzhall, M., Ariyanto, E., Agistiawati, E., Sudiyono, R. N., Waruwu, H., Goestjahjanti, F. S., Winanti, \& Yuwono, T. (2020). Peran Religiusitas, Kepemimpinan Transformasional, Kepuasan Kerja Dan Mediasi Organizational Citizenship Behavior Terhadap Kinerja Guru. Edupsycouns: Journal Of Education, Psychology And Counseling, 2(1), 311-326. Https://Ummaspul.E-Journal.Id/Edupsycouns/Article/View/483

Im, T., Campbell, J. W., \& Jeong, J. (2016). Commitment Intensity In Publik Organizations: Performance, Innovation, Leadership, And Psm. Review Of Publik Personnel Administration, 36(3), 219-239. Https://Doi.Org/10.1177/0734371x13514094

Jensen, U. T., \& Bro, L. L. (2018). How Transformational Leadership Supports Intrinsic Motivation And Publik Service Motivation: The Mediating Role Of Basic Need Satisfaction. American Review Of Publik Administration, 48(6), 535-549. Https://Doi.Org/10.1177/0275074017699470

Johan, M., Budiadnyana, G. N., Admiral, Asbari, M., \& Novitasari, D. (2021a). Kepemimpinan Karismatik Dalam Perspektif Karyawan Umkm: Dari Motivasi Intrinsik Hingga Tacit Knowledge Sharing. 
4183 Urgensi Menumbuhkan Motivasi Pelayanan Publik Pegawai Puskesmas: Analisis Servant Leadershipdan Mediasi Basic Need Satisfaction - Muhamad Agung Ali Fikri, Lala Hucadinota Ainul Amri, Multi Nadeak, Dewiana Novitasari, Masduki Asbari DOI: https://doi.org/10.31004/edukatif.v3i6.1421

Edumaspul: Jurnal Pendidikan, 5(1), 598-613. Https://Ummaspul.EJournal.Id/Maspuljr/Article/View/1303

Johan, M., Budiadnyana, G. N., Admiral, Asbari, M., \& Novitasari, D. (2021b). Kepemimpinan Karismatik Dalam Perspektif Karyawan Umkm: Dari Motivasi Intrinsik Hingga Tacit Knowledge Sharing. Edumaspul: Jurnal Pendidikan, 5(1), 598-613.

Jumiran, Novitasari, D., Nugroho, Y. A., Sutardi, D., Sasono, I., \& Asbari, M. (2020). Pengaruh Dimensi Kepemimpinan Transformasional Terhadap Kepuasan Kerja Dan Komitmen Organisasional: Studi Kasus Pada Dosen Perguruan Tinggi Swasta. Edupsycouns: Journal Of Education, Psychology And Counseling, 2(1), 600-621. Https://Ummaspul.E-Journal.Id/Edupsycouns/Article/View/555

Latif, K. F. (2021). Servant Leadership, Career, And Life Satisfaction In Higher Education: A Cross-Country Study Of Spain, China, And Pakistan. Applied Research In Quality Of Life, 16(3), 1221-1247. Https://Doi.Org/10.1007/S11482-019-09809-X

Law, K. S., Wong, C.-S., \& Song, L. J. (2004). The Construct And Criterion Validity Of Emotional Intelligence And Its Potential Utility For Management Studies. Journal Of Applied Psychology, 89(3), 483.

Lin, C., \& Peng, T. (2010). From Organizational Citizenship Behaviour To Team Performance: The Mediation Of Group Cohesion And Collective Efficacy. Management And Organization Review, 6(1), $55-75$.

Mahmood, S., Muhammad, R., \& Farooq, A. (2020). Investigating The Impact Of Transformational Leadership On Employee Innovative Behavior And Job Performance: The Mediating Role Of Publik Service Motivation Abstract :40(1), 455-465.

Mehta, A., Feild, H., Armenakis, A., \& Mehta, N. (2009). Team Goal Orientation And Team Performance: The Mediating Role Of Team Planning. Journal Of Management, 35(4), 1026-1046.

Novitasari, D., \& Asbari, M. (2021a). Leaders Coaching Di Sekolah: Apa Perannya Terhadap Kinerja Guru? Edumaspul: Jurnal Pendidikan, 5(1), 580-597.

Novitasari, D., \& Asbari, M. (2021b). Leaders Coaching Di Sekolah: Apa Perannya Terhadap Kinerja Guru? Edumaspul: Jurnal Pendidikan, 5(1), 580-597. Https://Ummaspul.EJournal.Id/Maspuljr/Article/View/1299

Novitasari, D., Asbari, M., \& Purwanto, A. (2020). Maximizing Employee Performance: An Analysis Of Organizational And Individual Factors. International Journal Of Social And Management Studies, 1(1), 95-104.

Novitasari, D., Asbari, M., Purwanto, A., Iskandar, J., Sutardi, D., Silitonga, N., \& Putra, A. S. (2020). Peran Social Support Terhadap Work Conflict, Kepuasan Dan Kinerja. Jurnal Penelitian Ilmu Manajemen (Jpim), 5(2), 187-202. Https://Doi.Org/Http://Dx.Doi.Org/10.30736\%2fjpim.V5i2.350

Novitasari, D., Asbari, M., Putra, F., Kumoro, D. F. C., \& Fikri, M. A. A. (2021). Tacit Knowledge Sharing Di Sekolah Islam: Analisis Kepemimpinan Dan Iklim Keamanan Psikologis. Cetta: Jurnal Ilmu Pendidikan, 4(2), 138-162. Http://Jayapanguspress.Penerbit.Org/Index.Php/Cetta/Article/View/1287

Novitasari, D., Asbari, M., \& Sasono, I. (2021a). Analisis Pengaruh Religiusitas Dan Kualitas Pelayanan Terhadap Kepuasan Kerja: Studi Kasus Pada Karyawan Industri Manufaktur. Jurnal Manajemen Strategi Dan Aplikasi Bisnis, 4(1), 117-130.

Novitasari, D., Asbari, M., \& Sasono, I. (2021b). Pengaruh Religiusitas Dan Kualitas Pelayanan Terhadap Kepuasan Kerja. Jurnal Manajemen Strategi Dan Aplikasi Bisnis, 4(1), 117-130. Https://Doi.Org/Https://Doi.Org/10.36407/Jmsab.V4i1.268

Novitasari, D., Hutagalung, D., Amri, L. H. A., Nadeak, M., \& Asbari, M. (2021). Kinerja Inovasi Di Era Revolusi Industri 4.0: Analisis Knowledge-Oriented Leadership Dan Kapabilitas Manajemen 
4184 Urgensi Menumbuhkan Motivasi Pelayanan Publik Pegawai Puskesmas: Analisis Servant Leadershipdan Mediasi Basic Need Satisfaction - Muhamad Agung Ali Fikri, Lala Hucadinota Ainul Amri, Multi Nadeak, Dewiana Novitasari, Masduki Asbari DOI: https://doi.org/10.31004/edukatif.v3i6.1421

Pengetahuan. Edukatif: Jurnal Ilmu Pendidikan, 3(4), 1245-1260.

Novitasari, D., Supiana, N., Supriatna, H., Fikri, M. A. A., \& Asbari, M. (2021). The Role Of Leadership On Innovation Performance: Transactional Versus Transformational Style. Jimfe (Jurnal Ilmiah Manajemen Fakultas Ekonomi), 7(1), 27-36. Https://Journal.Unpak.Ac.Id/Index.Php/Jimfe/Article/View/2981

Nugroho, Y. A., Putra, F., Novitasari, D., Asbari, M., \& Purwanto, A. (2021). Developing Innovation Capability: Between Individual And Organizational Factors. International Journal of Social And Management Studies (Ijosmas), 1(01), 74-88.

Nuryanti, Y., Novitasari, D., Nugroho, Y. A., Fauji, A., Gazali, \& Asbari, M. (2020). Meningkatkan Komitmen Organisasional Dosen: Analisis Pengaruh Kepemimpinan Perguruan Tinggi Dan Kepuasan Intrinsik \& Ekstrinsik Dosen. Edupsycouns: Journal Of Education, Psychology And Counseling, 2(1), 561-581. Https://Ummaspul.E-Journal.Id/Edupsycouns/Article/View/551

Purwanto, A., Asbari, M., \& Santoso, T. I. (2021a). Analisis Data Penelitian Manajemen Pendidikan: Perbandingan Hasil Antara Amos, Smartpls, Warppls, Dan Spss Untuk Jumlah Sampel Kecil. International Journal of Social, Policy And Law (Ijospl), 01(01), 111-122. Https://Ijospl.Org/Index.Php/Ijospl/Article/View/64

Purwanto, A., Asbari, M., \& Santoso, T. I. (2021b). Education Management Research Data Analysis: Comparison Of Results Between Lisrel, Tetrad, Gsca, Amos, Smartpls, Warppls, And Spss For Small Samples. Nidhomul Haq: Jurnal Manajemen Pendidikan Islam, 6(2), 382-399. Https://EJournal.Ikhac.Ac.Id/Index.Php/Nidhomulhaq/Article/View/1575

Purwanto, A., Asbari, M., Santoso, T. I., Haque, M. G., \& Nurjaya. (2019). Marketing Research Quantitative Analysis For Large Sample: Comparing Of Lisrel, Tetrad, Gsca, Amos, Smartpls, Warppls, And Spss. Jurnal Ilmiah Ilmu Administrasi Publik: Jurnal Pemikiran Dan Penelitian Administrasi Publik, 9(2), 355-372. Https://Ojs.Unm.Ac.Id/Iap/Article/View/22803

Purwanto, A., Asbari, M., Santoso, T. I., Paramarta, V., \& Sunarsih, D. (2020). Social And Management Research Quantitative Analysis For Medium Sample: Comparing Of Lisrel, Tetrad, Gsca, Amos, Smartpls, Warppls, And Spss. Jurnal Ilmiah Ilmu Administrasi Publik: Jurnal Pemikiran Dan Penelitian Administrasi Publik, 9(2), 518-532. Https://Ojs.Unm.Ac.Id/Iap/Article/View/22804

Purwanto, A., Asbari, M., Santoso, T. I., Sunarsi, D., \& Ilham, D. (2021). Education Research Quantitative Analysis For Little Respondents: Comparing Of Lisrel, Tetrad, Gsca, Amos, Smartpls, Warppls, And Spss. Jurnal Studi Guru Dan Pembelajaran, 4(2), 335-350. Https://EJournal.My.Id/Jsgp/Article/View/1326

Purwanto, A., Bernarto, I., Asbari, M., Wijayanti, L. M., Choi, \&, \& Hyun, C. (2020). The Impacts Of Leadership And Culture On Work Performance In Service Company And Innovative Work Behavior As Mediating Effects. Journal Of Reseacrh In Business, Economics, And Education, 2(1), 283-291. Http://E-Journal.Stie-Kusumanegara.Ac.Id

Purwanto, A., Hidayat, D., \& Asbari, M. (2021). Work-Family Conflict Disaster: From Organizational Commitment To Job Satisfaction. International Journal Of Social And Management Studies (Ijosmas), 02(01), 86-92. Https://Doi.Org/Https://Doi.Org/10.5555/Ijosmas.V2i1.13

Putra, F., Asbari, M., Purwanto, A., Novitasari, D., \& Santoso, P. B. (2021). Linking Social Support And Performance In Higher Education. International Journal Of Social And Management Studies (Ijosmas), 01(01), 64-73. Https://Doi.Org/Https://Doi.Org/10.5555/Ijosmas.V2i1.8

Rezvani, A., Khosravi, P., \& Dong, L. (2017). Motivating Users Toward Continued Usage Of Information Systems: Self-Determination Theory Perspective. Computers In Human Behavior, 76, 263-275. Https://Doi.Org/10.1016/J.Chb.2017.07.032

Sekaran, U., \& Bougie, R. (2016). Research Methods For Business: A Skill Building Approach. John Wiley \&Sons. 
4185 Urgensi Menumbuhkan Motivasi Pelayanan Publik Pegawai Puskesmas: Analisis Servant Leadershipdan Mediasi Basic Need Satisfaction - Muhamad Agung Ali Fikri, Lala Hucadinota Ainul Amri, Multi Nadeak, Dewiana Novitasari, Masduki Asbari DOI: https://doi.org/10.31004/edukatif.v3i6.1421

Shim, D. C., \& Faerman, S. (2017). Government Employees' Organizational Citizenship Behavior: The Impacts Of Publik Service Motivation, Organizational Identification, And Subjective Ocb Norms. International Publik Management Journal, 20(4), 531-559.

Silitonga, N., Johan, M., Asbari, M., Hutagalung, D., \& Novitasari, D. (2021). Mengelola Kinerja Tim Engineering: Dari Iklim Kecerdasan Emosional Hingga Team Efficacy. Value : Jurnal Manajemen Dan Akuntansi, 16(1), 172-187. Https://E-Journal.Umc.Ac.Id/Index.Php/Vl/Article/View/1839

Spears, L. C. (2010). Character And Servant Leadership: Ten Characteristics Of Effective, Caring Leaders. The Journal Of Virtues \& Leadership, 1(1), 25-30.

Sudiyono, R. N., Goestjahjanti, F. S., Asbari, M., Agistiawati, E., Fayzhall, M., Yani, A., Winanti, W., Yuwono, T., Nurasiah, N., \& Yulia, Y. (2020). Meningkatkan Komitmen Dan Kinerja Dosen: Apa Peran Manajemen Perguruan Tinggi? Edupsycouns: Journal Of Education, Psychology And Counseling, 2(1), 337-352.

Suroso, Riyanto, Novitasari, D., Sasono, I., \& Asbari, M. (2021a). Esensi Modal Psikologis Dosen: Rahasia Kreativitas Dan Inovasi Di Era Education 4.0. Edumaspul - Jurnal Pendidikan, 5(1), 437-451.

Suroso, Riyanto, Novitasari, D., Sasono, I., \& Asbari, M. (2021b). Esensi Modal Psikologis Dosen: Rahasia Kreativitas Dan Inovasi Di Era Education 4.0. Edumaspul - Jurnal Pendidikan, 5(1), 437-451. Https://Ummaspul.E-Journal.Id/Maspuljr/Article/View/1240

Sutardi, D., Novitasari, D., Asbari, M., Silitonga, N., Nugroho, Y. A., Hutagalung, D., Mustofa, Chidir, G., Basuki, S., \& Yuwono, T. (2020). Pengaruh Work-Family Conflict, Stres Kerja Dan Social Support Terhadap Kepuasan Kerja: Studi Kasus Pada Guru Wanita Di Tangerang. Edupsycouns: Journal Of Education, Psychology And Counseling, 2(1), 482-498. Https://Ummaspul.EJournal.Id/Edupsycouns/Article/View/513

Tangaraja, G., Rasdi, R. M., Ismail, M., \& Samah, B. A. (2015). Fostering Knowledge Sharing Behavior Among Publik Sector Managers: A Proposed Model For The Malaysian Publik Service. Journal Of Knowledge Management, 19(1), 121-140. Https://Doi.Org/10.1108/Jkm-11-2014-0449

Weller, I., Süß, J., \& Wangenheim, F. Von. (2019). Transformational Leadership, High-Performance Work System Consensus , And Customer Satisfaction. Xx(X), 1-29. Https://Doi.Org/10.1177/0149206318817605

Yuwono, T., Novitasari, D., Asbari, M., Sutardi, D., Mustofa, \& Asbari, M. (2020). Peran Organizational Commitment Terhadap Hubungan Work- Family Conflict Dan Kepuasan Kerja Karyawan Wanita Di Kota Seribu Industri Tangerang. Edupsycouns: Journal Of Education, Psychology And Counseling, 2(1), 524-540. Https://Ummaspul.E-Journal.Id/Edupsycouns/Article/View/526/303

Yuwono, T., Novitasari, D., Hutagalung, D., Sasono, I., Silitonga, N., \& Asbari, M. (2020). Peran Organizational Justice Terhadap Komitmen Organisasional: Analisis Mediasi Kepuasan Kerja Dosen Perguruan Tinggi Swasta. Edupsycouns: Journal Of Education, Psychology And Counseling, 2(1), 582 599. Https://Ummaspul.E-Journal.Id/Edupsycouns/Article/View/550 